\title{
A CALL FOR A PROTOCOL TO THE AFRICAN CHARTER ON HUMAN AND PEOPLES' RIGHTS ON THE RIGHTS OF PERSONS WITH DISABILITIES IN AFRICA
}

\author{
SERGES ALAIN DJOYOU KAMGA*
}

\section{INTRODUCTION}

Central to the discourse on disability is the question of systemic disadvantage, characterised by the discrimination, and often complete exclusion, of persons with disabilities (PWDs) in society. In an effort to address the problem, on 13 December 2006, the international community adopted the UN Convention on the Rights of Persons with Disabilities (CRPD), which entered into force together with its Optional Protocol on 3 May 2008.

In Africa, prior to the advent of the CRPD, the idea of a specific treaty on disability rights had surfaced in 2003 at the first AU Ministerial Conference on Human Rights in Africa. During this meeting, African leaders recognised the broad violation of the rights of "vulnerable groups including persons with disability in general' and called for the adoption of 'a Protocol on the protection of the rights of people with disabilities and the elderly'. This call was answered in 2009 when the African Commission on Human and Peoples' Rights (the African Commission) set a Working Group on the Rights of Older Persons and People with Disabilities to draft a concept paper that would serve as the basis for the adoption of a draft Protocol on the Elderly and People with Disabilities.' The Working Group developed two draft protocols - one for the rights of older persons and the other one being the draft protocol on the rights of PWDs - at an expert meeting held in Accra, Ghana, hence the draft protocol on the rights of PWDs is called the 'Accra draft".

However, the Accra draft was put on hold at the 49th Ordinary Session of the African Commission (28 April-12 May 2011) for further reflection.

* Lic-en dt (Yaounde II), LLM (Human Rights and Constitutional Practice), (Pretoria), LLD (Human Rights Law) (Pretoria), Researcher Centre for Human Rights, University of Pretoria. This paper was presented at the first international conference: Disability and the Majority World: Towards a Global Disability Studies held at Elizabeth Gaskell Campus, Manchester Metropolitan University, 7-8 July 2011.

1 Resolution on the Transformation of the Focal Point on the Rights of Older Persons in Africa into a Working Group on the Rights of Older Persons and People with Disabilities in Africa, ACHPR/Res $143($ XXXXV)09. 
This development brings to the table the question of what could be the appropriate instrument for the protection of disability rights in Africa, especially after the coming into force of the CRPD already ratified by twenty-six African states. In addition, the continent has an existing disability law regime made of four treaties already in force, ${ }^{2}$ two treaties not yet in force $^{3}$ and numerous activities of the African Commission through its Working Group on the Rights of Older Persons and People with Disabilities, its reporting and communication procedures, its thematic resolutions of guidelines and general comments. Furthermore, there is a plethora of non-binding instruments dealing with disability issues on the continent.

The African Charter on Human and Peoples' Rights (the African Charter) permits the adoption of 'special protocols or agreement to supplement [its] provisions'. Therefore, in contributing to the debate, this paper calls for the adoption of a protocol to the African Charter on the rights of PWDs on the grounds that it will not only assist in deepening and supplementing the CRPD on the continent, but will also strengthen the African Charter's provisions and other aspects of the continental disability law regime in general. In making the case for a protocol, the paper analyses and stresses the advantages and disadvantages of a protocol in comparison with other options.

In terms of structure, the paper is divided into five parts. In order to highlight the urgency of an efficient response to violations of disability rights on the continent, the second part presents an overview of disability in Africa; the third part assesses inter alia the desirability, feasibility and implementation of a protocol in the light of the Accra draft. It also proceeds to examine the desirability of a protocol in the light of the CRPD and in the light of the current African disability legal framework. The fourth part of the paper discusses the potential contents of the protocol and the final part provides concluding remarks.

\section{DISABILITY IN AFRICA: AN OVERVIEW}

According to the CRPD, PWDs comprise those who have long-term physical, mental, intellectual or sensory impairments which in interaction with various barriers may hinder their full and effective participation in society on an equal

2 The African Charter on Human and Peoples' Rights (African Charter) (adopted in 1981, entered into force in 1986), reprinted in C. Hyens and M. Killander (eds), Compendium of Key Human Rights Documents of the African Union, Pretoria University Law Press (2010), pp. 29-40; the African Charter on the Rights and Welfare of the Child (African Children's Charter) (adopted in 1990, entered into force in 1999), reprinted in Hyens and Killander, pp. 77-89; the Protocol on the Rights of Women in Africa (African Women's Protocol) (adopted in 2003, entered into force in 2005), reprinted in Hyens and Killander, pp. 61-7; the African Youth Charter (adopted in 2006, entered into force 2009), reprinted in Hyens and Killander, pp. 118-31.

3 African Charter on Democracy, Elections and Good governance (Charter on Democracy) (adopted in 2007, has yet to enter into force), reptinted in Hyens and Killander, supra note 2, pp. 131-42; the AU Convention for the Protection and Assistance of Internally Displaced Persons in Africa (IDP Convention) (adopted in 2009 , has yet to enter into force), reprinted in Hyens and Killander, supra note 2, pp. 143-54.

4 African Charter, supra note 2, article 66. 
basis with others. ${ }^{5}$ It is estimated that 80 million people live with some form of disability in Africa. ${ }^{6}$ In this part of the world, these people include albinos who suffer a sensory impairment and are considered as PWDs. ${ }^{7}$

PWDs in general live in abject poverty and are vouchsafed with charity and placed under social welfare programmes due their inability to function in mainstream society and to provide for themselves. ${ }^{8}$ Poverty in PWDs' communities is linked to insufficient access to education, employment, health care and other social services that characterise the life of PWDs. The Kenyan Human Rights Commission summarises the situation in these terms:

The poverty levels which persons with disabilities face are far higher relative to the rest of society. The opportunities for livelihood available to a disabled person are less obvious since disability undermines the actual or perceived ability of a person to interact in educational, economic, social or indeed political arenas. Poverty itself breeds disability and disability is a harbinger for more poverty."

Indeed, in Africa, one of the most challenging issues related to disabilities is extreme poverty. According to Chalklen et al.,

The situation in Africa differs radically from that in the US or Europe for a number of reasons. Most fundamental is the issue of poverty. Severe poverty not only disempowers PWDs, but hinders their survival ability. For example, though a person with a spinal cord injury in a wealthier country, or even in South Africa, has a long life expectancy, some have estimated the life expectancy for a person with a spinal cord injury in a poorer African country at between four months and two years, and similar challenges face people with other impairments. ${ }^{10}$

5 The United Nations Convention on the Rights of Persons with Disabilities (CRPD) was adopted by the United Nations General Assembly on 13 December 2006 and entered into force on 3 May 2008 , available at http:/www.un.org/disabilities/convention/conventionfull.shtml\#top (accessed 25 February 2013). See article 1.

6 'Disability in Africa', available at http:/wwwascleiden.nl/Library/Webdossiers/ DisabilityInAfrica.aspx (accessed 6 December 2010).

7 T. Choruma, The Forgotten Tribe: People with Disabilities in Zimbabwe, Progressio (2007), p. 10. This is also the view of the Secretariat of the African Decade of Persons with Disabilities (see pamphlet issued at the 2011 Roundtable to Develop the New Continental Disability Strategy for the Aftican Decade of Persons with Disability 2010-2019).

8 C. Ngwena, "Deconstructing the Definition of "Disability" Under the Employment Equity Act: Social Deconstruction' 22 South African Journal on Human Rights (2006): 613-20. Also D. Goodley, Disability Studies - An Interdisciplinary Introduction, Sage Publications (2011).

9 Report of Kenya National Human Rights Commission, Objects of Pity or Individuals with Rights: The Right to Education for Children with Disabilities (2007). Quoted in H. Kotze, A Situational Analysis of the State and Stanis of Disability Issues and Rights in Southern Africa: OSISA Project on Disability Rights and Law, OSISA (2010), p. 16.

10 S. Chalklen, L. Swart and B. Watermeyer, 'Establishing the Secretariat for the African Decade of Persons with Disabilities', in B. Watermeyer, L. Swart, T. Lorenzo, M. Schneider and M. Priestley (eds), Disability and Social Change: A South African Agenda, Human Science Research Council Press (2006), p. 96. 
PWDs also suffer stigma and discrimination and are highly vulnerable to HIV/AIDS." In fact, the trademark feature of disability in Africa is "voicelessness' and institutional neglect of disabled people, who are often forced to take positions on the outermost margins of their societies'. ${ }^{12}$ The marginalisation of PWDs is often the result of traditional or cultural beliefs. For example, in Swaziland, the only contemporary African monarchy, custom prevents PWDs from taking part in some national or cultural events on the ground that 'a disabled person making contact or coming close to royalty will actually bring bad luck to either the king or the queen mother". ${ }^{13}$

In a similar vein, based on traditional beliefs, children with disabilities are considered to be 'disgrace' to their families who hide them or deprive them of any contact with the rest of the community as they symbolise the punishment of gods on the family. ${ }^{14}$ In this regard, a child with a disability is considered to represent 'a bad omen that may tarnish the family pedigree'. ${ }^{15}$ However, Kisanji has reservations about this view, and argues that children with disabilities are kept at home, not out of guilt but to be protected and looked after. ${ }^{16}$ Nonetheless, Kisanji also recognises that societal reactions to disabilities differ depending on the type of disability, hence illnesses such as leprosy or albinism have been considered as a curse or witchcraft. ${ }^{17}$

Besides children with disabilities, women with disabilities (WWDs) are also vulnerable to several abuses linked to their disability. They suffer double discrimination, for being a woman and for having a disability. ${ }^{18}$ As a result, poverty, joblessness, misery and social exclusion are the plight of these women. In terms of health care, women and girls with disabilities are exposed to sexual violence and rape and, consequently, to HIV/AIDS. ${ }^{19}$ Their vulnerability to sexual violence, rape and HIV is aggravated by the belief that sex with PWDs will cure AIDS - presumably an even more twisted version of the so-called 'virgin cure' that is grounded on the common misconception that people with disabilities are not sexually active and therefore have to be virgins. ${ }^{20}$

11 Kotze, supra note 9, p. 5.

12 M. Power, 'Geographies of Disability and Development in Southern Africa', 21 Disability Studies Quarterly (2001), available at http:/www.dsq-sds.org/article/view/320/388 (accessed 20 April 2011).

13 Kotze, supra note 9 , p. 35.

14 Goodley, supra note 8, p. 6.

$15 \mathrm{H}$. Combrinck, 'The Hidden Ones: Children with Disabilities in Africa and the Right to Education', in J. Sloth-Nielsen (ed.), Children's Rights in Africa: A Legal Perspective, Ashgate (2008), p. 302. Also Goodley, supra note 8, p. 14.

16 J. Kisanji, 'Growing Up Disabled', in P. Zinkin and H. McConachie (eds), Disabled Children in Developing Countries, Mac Keith Press (1995), p. 195, quoted in Combrinck, ibid., p. 302.

17 lbid., p. 302.

18 S. A. Djoyou Kamga, 'The Rights of Women with Disability in Africa: Does the Protocol on the Rights of Women in Africa Offer Any Hope?', Barbara Faye Waxman Fiduccia Papers on Women and Girls with Disabilities (2011), p. 2, available at htp:/www.centrewomenpolicy.org (accessed 19 April 2011).

19 Ibid., p. 3.

20 Ibid., p. 3. 
Overall, PWDs in Africa are poor, uneducated and marginalised. They suffer from several cultural and traditional beliefs and practices which not only broaden discrimination against them, but also keep children with disabilities behind closed doors, away from school and the community. Furthermore, PWDs, especially women are sexually abused and exposed to HIV/AIDS.

\section{THE DESIRABILITY OF AN AFRICAN PROTOCOL ON THE RIGHTS OF PWDS}

This section examines inter alia the desirability, feasibility and implementation of a protocol in the light of the Accra draft. It also assesses the desirability of a protocol in the light of the CRPD and in the light of the current African disability legal framework.

\section{A. The Accra Draft}

In 2009 , the plight of the elderly and PWDs was given special attention by the African Commission that transformed the Focal Point on the Rights of Older Persons to a Working Group on the Rights of Older Persons and People with Disabilities in Africa with a mandate to draft a concept paper that would serve as the basis for the adoption of a draft Protocol on the Elderly and People with Disabilities. Subsequent to the Ghana seminar that resulted in the Accra draft, another meeting of members of the Working Group was held in Balaclava, Mauritius from 9-11 August 2010, to finalise the draft Protocol on the Rights of Older Persons and to 'map out strategies to finalise the draft Protocol on the Rights of People with Disabilities' by $2011 .^{21}$ The Accra draft had been put on hold to allow further engagement and debate and this section contributes to the debate in light of the existing draft.

The Accra draft is not flawless. First, the Working Group went beyond its original mandate, which was to draft a concept paper that would inform the decision on the adoption of a protocol. Hence, the resultant draft was produced by a few people with no proper consultation with Disabled People Organisations (DPOs), and was characterised by insufficient 'analytical thinking and conceptual explanations'.$^{22}$ In fact, important stakeholders have rightfully complained that the process that led to the adoption of the Accra draft 'was not sufficiently inclusive of the participation of expert opinions of persons with disabilities'. ${ }^{23}$ As correctly

21 Report of Commissioner Y. K. J. Yeung Sik Yuen, Chairperson of the Working Group on the Rights of Older Persons and People with Disabilities in Africa (Inter-Session period, May 2010-November 2010), para. 18, available at http:/www.achpr.org/english/ Commissioner's\%20Activity/.../Young.doc (accessed 28 April 2011 ).

22 F. Viljoen, 'The Architecture for an African Disability Rights Treaty', ed. A. K. Dube, T. Ong'olo and B. Jele, a publication of the Secretariat of African Decade of Persons with Disabilities (2011), p. 34 .

23 'Communiqué on the Draft Disability Protocol', available at http://wwwafricandecade. org/humanightsafrica/newsletter.2010-11-17.1543715827, quoted in J. Biegon 'The Promotion and Protection of Disability Rights in the African Human Rights System' in T. van Reenen and 
observed by Mureriwa, even 'the African Union's very own disability rights Secretariat' known as the Secretariat for the African Decade for Persons with Disabilities (SADPD), was not invited to the drafting table. ${ }^{24}$

Second, in terms of substance, socio-economic rights provisions 'are weak and are a watered-down version of the international disability instrument'. ${ }^{25}$ The draft protocol fails to supplement the CRPD by an incorporation of African realities. It should have filled the gaps left by the CRPD. Regrettably, this has not happened because the Accra draft does not cover the questions of albinism and disability, does not establish a link between HIV/AIDS and disability, and does not deal with the question of ubuntu or the classical African humanist philosophy of kinship which unites mankind in a common purpose. ${ }^{26}$ The draft protocol is also silent on the effects of harmful traditional practices and does not underline the double discrimination suffered by WWDs. All these issues will be discussed at length in the section allocated to the desirability of the protocol in light of the CRPD.

Furthermore, the Accra draft excludes the concept of 'reasonable accommodation' and puts less emphasis on equality between PWDs and others, ${ }^{27}$ which are at the centre of disability rights discourse. In addition, the draft protocol also contains several typographical errors. ${ }^{28}$ However, notwithstanding the shortcomings and weaknesses of the draft protocol, it should not be abandoned. Africa and its people should build on this draft. It should be used as a working document to be improved upon, taking into account the need to strengthen existing African instruments on disability rights and not water down the gains achieved so far.

Instead of trying to reinvent the wheel, African countries can simply ratify and domesticate the CRPD and its Optional Protocol, especially because the global document already covers numerous issues pertaining to African PWDs. ${ }^{29}$ Disability rights have not improved in several African states parties to the CRPD, however; so far only Tunisia has submitted a report to the CRPD Committee that comprises only three African states among its eighteen members. ${ }^{30}$ The necessity of a protocol remains questionable because of the existing CRPD as well as the existence of an African disability law regime in binding and non-binding forms. Nonetheless, as will be shown below, the global disability treaty as well as the

I. Grobbelaar-du Plessis (eds), Aspect of Disability Law in Africa, Pretoria University Law Press (2011), pp. 53-83, at 74 .

24 J. Mureriwa, 'The Draft African Disability Protocol and Socio-Economic Justice for Persons with Disabilities', 12 Economic and Social Rights Review (2011): 3-6, at 3.

25 lbid., p. 3.

26 D. Tutu, No Future without Forgiveness, Doubleday (1999), p. 31.

27 F. Viljoen and J. Biegon, 'The Feasibility and Desirability of an African Disability Rights Treaty" (2011) (unpublished paper on file with author), pp. 10, 29.

28 For example, articles I(c), 5(c) and 6(b).

29 This will be discussed thoroughly below.

30 As at 19 October 2010 . Tunisia was the only African state to have submitted a report: Initial Report submitted by Tunisia under article 35 of the Convention on the Rights of Persons with Disabilities, CRPD/C/TUN/1, 1 July 2010; see http//www.ohchrorg/EN/HRBodies/CRPD/ Pages/Sessions.aspx. The three representative of Africa are Ms Fatiha Hadj Salah (Algeria), Ms Edah Wangechi Maina (Kenya) and Mr Lotfi Ben Lallahom (Tunisia). 
current continental disability legal framework have their own shortcomings that can be corrected by the protocol; but the adoption of the protocol should be done in consultation with all the relevant stakeholders, especially with DPOs.

The other alternative could be the adoption of a self-standing continental treaty on disability rights. Although the CRPD did not take long to come into force, the adoption of a treaty is in general time and resources consuming. In fact, it takes a difficult and prolonged period to prepare a treaty and after its adoption, it may still take years to come into force. While reflecting on the 'legal protection of indigenous peoples' rights in Africa', ${ }^{31}$ Viljoen rejects the idea of adopting a new protective treaty for indigenous peoples 'because time is of the essence'. ${ }^{32}$ Furthermore, unlike the protocol, which could be monitored through the already established African Commission (through its complaint and state reporting mechanisms), a self-standing treaty would entail creating another institution to monitor its implementation. The creation of an additional body not only wastes scarce resources, but comes with another obligation of states to report on what they do to give effect to the rights of PWDs. Nevertheless, under a new monitoring body, disability rights would be given more visibility and the body would be equipped with appropriate expertise, ${ }^{33}$ though a new treaty may lead not only to dispersion of efforts but also to unnecessary delays.

The Accra draft sets up a new motoring body, the Committee on the Rights of Persons with Disabilities in Africa. This approach should not be followed as the suggested protocol in this paper should use the African Commission which is already in place to ensure the monitoring and implementation of the protocol. Even if adopting a protocol is also time and resources consuming due to the period and resources allocated to drafting, adoption, ratification and domestication, as well as further reporting obligations, ${ }^{34}$ at least there is no need to establish a new institution on a continent already packed with monitoring bodies.

For a better promotion and implementation of the protocol, there is a need to depart from the Accra draft in which the Working Group is in charge of the elderly as well as PWDs. The Working Group must be separated into two: one in charge of the rights of PWDs and the other in charge of the elderly, as these are two different groups of vulnerable peoples with specific interests and

31 F. Viljoen, 'Reflections on the Legal Protection of Indigenous Peoples' Rights in Africa', in S. Dersso (ed.), Perspectives on the Rights of Minorities and Indigenous Peoples in Africa, Pretoria University Law Press (2010), pp. 75-93.

32 lbid., p. 93.

33 Viljoen, supra note 22, p. 38 .

34 At international level, the Report of the Human Rights Committee (volume 1), $A / 65 / 40$ (vol. 1), para. 51, observes that under the International Covenant on Civil and Policical Rights (ICCPR), twenty-five African states are listed amongst those states that have a report more than five years overdue; at regional level, the Report of the 48th Ordinary Session of the African Commission on Human and Peoples' Rights (2010) in its para. 87 notes that under the African Charter, for instance, only ten states are up to date in their submission of reports in accordance with article 62 of the Charter. For more on how African states are bogged down by reporting obligations, see Viljoen and Biegon, szipra note 27, pp. 33-4; I. Sloth-Nielsen and B. Mezmur, 'Like Running on a Treadmill? The 14th and 15th Sessions of the African Committee of Experts on the Rights of the Child', 10(2) African Human Rights Law Journal (2010): 534-56, at 534, 541. 
needs. Furthermore, for an efficient implementation of the protocol at country level and a well-organised monitoring at continental level, there is a need to adopt guidelines on state reporting on disability rights. The guidelines should assist in guaranteeing uniformity of states' reports on disability rights. Even though it is challenging to compel countries to comply with their human rights obligations, the guidelines could give them directions and they could be named and shamed for non-compliance. Moreover, the guidelines would also help PWDs to understand their rights and what is expected from their states, and therefore may also lead to more communications on disability rights being brought to the African Commission and the African Court of Justice.

Notwithstanding the difficulties attached to the adoption of a protocol, it would always enhance standard setting and strengthen the continental human rights system. Viljoen and Biegon observe that 'the role of the process of drafting, adoption, ratification and domestication [of the Protocol] is also likely to galvanise action and to provide symbolic and substantive normative guidance appropriate" to African disability issues. ${ }^{35}$ The protocol will focus the attention on the peculiar needs of African PWDs and harmonise the CRPD provisions with the continental disability legal framework.

Given that international law options are not necessarily mutually exclusive, the adoption of a protocol should not prevent African states from ratifying the CRPD and its Optional Protocol and ensure their domestication because these instruments can only enhance the prospects for better protection of disability rights.

\section{B. The desirability of an African protocol on the rights of PWDs in the light of the CRPD}

As alluded to earlier, both the UN CRPD ${ }^{36}$ and its Optional Protocol ${ }^{37}$ entered into force on 3 May 2008. An examination of the CRPD reveals that the document comprises a Preamble and fifty articles. In addition, the Optional Protocol consists of eighteen articles. Though the CRPD does not provide a definition of disability, the Preamble observes "that disability is an evolving concept and that disability results from the interaction between persons with impairments and attitudinal and environmental barriers that hinder their full and effective participation in society on an equal basis with others" ${ }^{38}$ This provision indicates the shift from the traditional social welfare model of disability to a human rights-based approach. Accordingly, PWDs are no longer viewed "as objects of charity, medical treatment

35 Viljoen and Biegon, supra note 27, p. 28.

36 For more on the convention, see G. Quinn and T. Degener, Human Rights and Disability: The Current Use and Future Potential of United Nations Human Rights Instruments in the Context of Disability, United Nations (2002), p. 1, available at http:/www.nhri.net/pdf/disability.pdf; M. A. Stein and J. E. Lord, 'Future Prospects for the United Nations Convention on the Rights of Persons with Disabilities', available at htp:/www.law.wisc.edu/m/zdq3n/2-20-09_steinlord_future_prospects_for_un_on_disability_rights.pdf (accessed 15 April 2011).

37 UN General Assembly by resolution A/RES/61/106.

38 CRPD, supra note 5, Preamble, para. (e). 
and social protection, [but] as subjects of rights able to claim those rights as active members of society'. 39

Article 3 offers the "moral compass" ${ }^{\text {"0 }}$ of the Convention through its general principles which include respect for individual dignity, autonomy and independence; respect for differences and acceptance of disability as human diversity; non-discrimination; equal opportunity; complete and meaningful social participation; accessibility; sexual equality; respect for children's rights and support of their evolving capacities. Articles 4-9 present the general obligations states assume on ratification or accession to the CRPD; articles 10-30 set out the specific human rights and fundamental freedoms recognised by the Convention; while articles 31-40 set out arrangements for implementation and monitoring of the convention at both the national and international levels. The content of the document led Kayess and French to argue that "the CRPD is, overall, the densest exposition of human rights by the UN to date' ${ }^{41}$ More importantly, Biegon correctly argues that:

The CRPD not only embodies African values, but it also addresses a wide range of concerns and issues [such as] the plight of both women and children with disabilities; ${ }^{42}$ the protection and safety of PWDs in situations of armed conflict, humanitarian emergencies and occurrences of natural disasters; ${ }^{43}$ and protection of PWDs from exploitation, violence and abuse $\mathrm{e}^{44}$ that are relevant to Africa. ${ }^{45}$

African voices were heard because African states, national human rights institutions, non-governmental organisations (NGOs) and individuals were

39 Statement by Louise Arbour, (former) UN High Commissioner for Human Rights on the Ad Hoc Committee's adoption of the International Convention on the Rights of Persons with Disabilities, 5 December 2006, available at http//wwwohchrorg/English/issues/disability/does/ statementhcdeco6.doc, quoted in R. Kayess and P. French, 'Out of Darkness into Light? Introducing the Convention on the Rights of Persons with Disabilities', 8 Human Rights Law Review (2008): 1-34, at 3. For more on the models of disability, see A. Hantis and S. Enfield, Disability, Equality, and Human Rights: A Training Manual for Development and Humanitarian Organizations, Oxfam (2003), pp. 14-18; G. Quinn and T. Degener, 'The Moral Authority for Change: Human Rights Values and the Worldwide Process of Disability Reform', in Quinn and Degener, supra note 36, p. 140; also K. C. Heyer, 'The ADA on the Road', 27 Law and Social Inquiry (2002): 723-62, at 726-7; A. S. Kanter, 'The Globalisation of Disability Rights Law', 30 Syracuse Joumal of International Law and Commerce (2003): 241-69, at 247.

40 G. Quinn, Key Note Address to German European Union Presidency Ministerial Conference: 'Empowering Persons with Disabilities, The UN Convention on the Human Rights of Persons with Disabilities: A Trigger for Worldwide Law Reform', Berlin, 11 June 2007, available at htp://www.eu2007.bmas.de/EU2007/Redaktion/Deutsch/PDF/2007-06-12rede-quinn, property $1 / 4$ pdf, bereich $1 / 4$ eu2007, sprachel/4de,rwb1/4true.pdf, quoted in Kayess and French, ibid., p. 27.

41 Kayess and French, supra note 39, p. 22.

42 CRPD, supra note 5 , articles 6 and 7.

43 CRPD, stipra note 5, article 11 .

44 CRPD, supra note 5, article 16.

45 Biegon, supra note 23. 
consulted and participated actively in the processes leading to the adoption of the final document. ${ }^{46}$

However, the CRPD like most international instruments is the fruit of a negotiated text. It is a compromise, which means some stakeholders had to forgo some of their interests. For example, during the CRPD drafting process, Kenya called for more imperative language ('... require...') to be used in article 21 in respect of private entities providing public information, in order to ensure that PWDs get such information. Unfortunately, the final text uses less imperative language ( $\ldots$ encourage ...'), a position favoured by the European Union and others. ${ }^{47}$ The other lack of consensus on the CRPD is the reservations entered by Mauritius and Egypt, even though these reservations are related to specific domestic concerns and not African general concerns. ${ }^{48}$ Furthermore, the request by South Africa to consider HIV/AIDS when elaborating the convention $^{49}$ was not taken into account as there is no reference to HIV in the final document.

As a result of the compromises, the CRPD is unlikely to reflect a harmonious and all-inclusive exposé of disability rights. ${ }^{50}$ Therefore, notwithstanding the broad and meaningful participation of African states and non-state actors ${ }^{51}$ in the adoption of the CRPD, the convention failed to cover some concerns of the African disability discourse including albinism, HIV/AIDS, and the effects of harmful traditional practices and beliefs on the rights of PWDs referred to earlier. It also failed to emphasise how the classical African humanist philosophy of kinship (ubuntu) could be used to the benefit of PWDs. These shortcomings will now be discussed.

46 Viljoen, supra note 22, pp. 12-17.

47 Communication from Adv Lawrence Mute, member of the Kenya National Human Rights Commission. According to Mute, the Kenyan position was based on the view that private entities abide by imperative provisions to protect the environment; and argued that a similar position should apply to ensure the rights of persons with disabilities. See also Viljoen and Biegon, supra note 27, p. 10.

48 Also see Viljoen and Biegon, supra note 27, p. 10. Though Egypt had participated in the drafting process, it insisted that the equality provision in article 12(2) implies the legal capacity of PWD to acquire rights and assume legal tesponsibility ("ahliyyat $a l-w i j i b$ ), but not the capacity to perform ('ahliyyat $a$-' $a d a$ '). Mauritius, on the other hand, 'declared' that it would not 'for the time being take any of the measures' as required under article $9(2)(\mathrm{d}) \&(\mathrm{e})$ 'in view of their heavy financial implication'. It also noted that the state has 'a policy of inclusive education which is being implemented incrementally alongside special education'.

49 This request was made during the second session of the AD Hoc Committee on a Comprehensive and Integral International Convention to Promote the Rights and Dignity.

50 Kayess and French, supra note 39, p. 33.

51 The participation was meaningful because Africa's position that disability should be addressed within the context of poverty and development is well captured in the Preamble to the CRPD where member states emphasise 'the importance of mainstreaming disability issues as an integral part of relevant strategies of sustainable development' (CRPD, supra note 5, Preamble, para. (g)); in addition, the emphasis on the link between poverty and disability is another African view that found its way into the Preamble, para. ( $\mathrm{t}$. 


\section{The CRPD and albinism}

There is controversy over whether albinism is a disability. This condition is covered as a sensory impairment under the CRPD's definition of disability ${ }^{52}$ and is considered as such. ${ }^{53}$ Albinos have a highly sensitive skin which is abnormally sensitive to light. In addition, they have limited visual capacity. As a result of their sensory and visual impairments, albinos are being killed in African countries, especially in Tanzania, because of the common belief that their body parts can add energy to black magic rituals. ${ }^{54}$ The killing of albinos for body parts is also a reality in some Eastern and Central African countries including Kenya and Uganda. According to the International Federation of Red Cross and Red Crescent Societies, thousands of people with albinism in Tanzania and Kenya have left their homes in villages out of fear of persecution and moved to live in urban areas where it is fairly safe. ${ }^{55}$

In spite of the murder of albinos in Africa, the CRPD is silent on the question and yet albinism is a disability. To the extent that people are killed because they are albinos, it follows that they are killed because of their disability. As such, their right to life is violated on the basis of their disability status.

It is contended that the lack of definition of disabilities by the CRPD enables states and regions to contextualise disabilities issues to their realities and address them accordingly. In this respect, the African protocol should be welcomed as it will be vital in such an endeavour. Nevertheless, to save time and resources, state reporting and the thematic resolutions of the African Commission could be the way to protect albinos.

State reporting provides an appropriate avenue for constructive conversations between the treaty bodies and states parties on the measures taken to give effect to human rights. According to article 62 of the African Charter, every two years states parties should submit reports on legislative and other measures they have taken to comply with the provisions of the African Charter. Unfortunately, through this mechanism, states' reports will mostly contain measures to protect the right to life in general without specific reference to albinos, hence the disability right is not addressed. This is so because there is no specific provision on albinism in the African Charter in spite of the general prohibition on discrimination under article 2 of the Charter. ${ }^{56}$

As far as resolutions and general comments are concerned, they are provided for under article $45(1)$ (b) of the African Charter. Accordingly, the African Commission is required to adopt resolutions and general comments to promote

52 CRPD, supra note 5, article 2(e).

53 Choruma, supra note 7.

54 'Albinos Hunted for Body Parts in Africa', The Telegraph, 10 April 2011. This information is from the Albino Association of Tanzania, available at http:www.slate./com/id/2208026 (accessed 10 April 2011).

55 International Federation of Red Cross and Red Crescent Societies, Albinos Still Targeted for Body Parts', available at http:/allafrica.com/stories/201102111011.html (accessed 11 April 2011).

56 This will be discussed further in the section allocated to the African disability law regime below. 
human rights. It should 'formulate and lay down principles and rules aimed at solving legal problems relating to human and peoples' rights and fundamental freedom' to inform national legislations. Even though resolutions and general comments are of considerable value in better understanding the norms and implementation problems in the legal system of African countries', ${ }^{57}$ they lack the legal force attached to a fully fledged protocol on the rights of PWDs including albinos. Besides, the right of albinos may not be quickly addressed through a selfstanding treaty which may only overburden the continent.

The African Children's Charter also compels states parties to submit reports on measures taken to give effect to the Charter within two years of becoming a member and thereafter every three years. ${ }^{58}$ But like the state reporting under the African Charter, this does not benefit children with albinism, who are not explicitly covered.

\section{The CRPD and HIV/AIDS}

Despite the international recognition that PWDs are vulnerable to HIV/AIDS, ${ }^{59}$ the CRPD is silent on the link between disability and HIV. The latter is the most serious global epidemic with Sub-Saharan Africa having to deal with the majority of victims. ${ }^{60}$ According to Swart et al., 'more people die of AIDS related illness in sub-Saharan Africa than of any cause'. ${ }^{61}$ In terms of systematic largescale research, the impact of HIV/AIDS on PWDs has been widely ignored. ${ }^{62}$ Therefore, PWDs are constantly at risk of becoming HIV-positive, and once they get the disease, are much less likely to get assistance or services. ${ }^{63}$

As noted earlier, PWDs, specifically women and children, are highly at risk of sexual violence, which exposes them to a higher risk of contracting HIV. They also have little or no access to HIV education, information and prevention services. ${ }^{64}$ Moreover, HIV-positive people are likely to develop disability. A study on HIV prevalence in South Africa, for example, shows that the prevalence among PWDs is higher than the national average. ${ }^{65}$

57 U. Nsongura, 'The African Commission on Human and Peoples' Rights and the Development of Fair Trial Norms in Africa", 6 African Human Rights Law Joumal (2006): 299-306.

58 African Children's Charter, supra note 2, article 43.

59 L. Gerntholtz, K. Grant and J. Hanass-Hancock, 'Disability Rights and HIV/AIDS in Eastern and Southern Africa: A Review of International, Regional and National Commitments on Disability Rights in the Context of HIV/AIDS in Eastern and Southern Africa', HEARD (2010), p. 3, available at http:/www.heard.org.za/downloads/disability-rights-and-hiv-aids-in-easternand-southern-africa.pdf (accessed 28 April 2011).

60 L. Swart, M. Schneider and P. Rohleder, 'HIV/AIDS and Disability: New Challenges', in Watermeyer et al. (eds), supra note 10 , p. 108.

61 lbid., p. 108.

62 lbid., p. 108.

63 M. McElligott, 'Disabled People at Significantly Increased Risk of HIV Infection', 2 December 2003, available at htp:/allafrica.com/stories/200312020521.html (accessed 23 April 2011).

64 Djoyou Kamga, supra note 18, p. 4.

65 O. Shisana, T. Rehle, L. C. Simbayi, K. Zuma, S. Jooste, V. Pillay-van-Wyk, N. Mbelle, J. Van Zyl, W. Parker, N. P. Zungu, S. Pezi and the SABSSM III Implementation Team, South Africa HV Prevalence, Incidence, Behavior and Communication Survey 2008: A Turning Tide Among Teenagers, HSRC Press (2009). 
Nonetheless, it could be argued that the rights provided for by the CRPD cover all PWDs including those who are HIV-positive. Gerntholtz et al. argue that 'key concepts within the CRPD are relevant to the protection of people with disabilities from HIV, as well as to the protection of the rights of people living with HIV who experience disablement' ${ }^{66}$ For example, concepts such as "universal design ${ }^{967}$ and 'reasonable accommodation' ${ }^{68}$ are vital in ensuring that PWDs who are HIVpositive are afforded the same rights to health and HIV-related programmes, products and services as other member of society. This is clearly highlighted by article 25(a) of the CRPD, which calls on states parties to: 'Provide persons with disabilities with the same range, quality and standard of free or affordable health care and programmes as provided to other persons, including in the area of sexual and reproductive health and population-based public health programmes. ${ }^{, 69}$ The problem with such an approach, however, is that it does not mention HIV specifically. Consequently, PWDs are not included when fighting HIV/AIDSrelated stigma and discrimination. In this regard, Nkosi Johnson, the HIV activist child who subsequently died of AIDS-related illness, made the following request at the thirteenth international AIDS Conference in Durban, South Africa:

I want people to understand AIDS, to be careful and respect AIDS. You can't get AIDS if you touch, hug, kiss or hold hands with someone who is infected. Care for us and accept us. We are all human beings. We are normal. We have hands, we have feet. We can walk, we can talk, we have needs just like someone else. Don't be afraid of us. We are all the same? $?^{70}$

Though Nkosi's request is commendable, it does not apply to HIV-positive PWDs who cannot walk or talk. The CRPD's silence on HIV/AIDS is unfortunate, hence the need to have an African protocol on the rights of PWDs that addresses their HIV-related concerns. Such a protocol should specifically focus on mainstreaming disability in HIV programming as this will assist HIV-positive PWDs to access HIV-related services such as counselling, testing and treatment, as all other members of society can.

Notwithstanding the reputation of the CRPD as the fastest negotiated treaty ever, ${ }^{71}$ the omission related to HIV/AIDS is problematic because of the statistics collected during a review of the National Strategic Plans (NSPs) on HIV and ADS of eighteen focus countries in Eastern and Southem Africa (ESA), which shows

66 Gerntholtz et al, supra note 59, p. 9.

67 CRPD, supra note 5 , article 2.

$68 \mathrm{lbid}$

69 For more discussion of this provision on the perspective of protecting HIV-positive PWDs, see S. Peake, 'Meeting Report of the International Policy Dialogue on HIV/AIDS and Disability', 12 Joumal of the International AIDS Society (2009): 2.

70 Nkosi's speech, quoted in Chalklen et al, supra note 10, p. 110.

71 Official Statement of the UN Secretary-General, 'Secretary General Hails Adoption of Landmark Convention on Rights of People with Disabilities', 13 December 2006, SG/SM/10797, HR/4911, L/T/4400, available at http//www.un.org/News/Press/docs/2006/sgsm10797.dochtm, quoted in Kayess and French, supra note 39, p. 2. 
that PWDs are still excluded. The report exposes five important points. First, all of the countries have multi-sectoral institutions to conduct the national response to HIV, but only three countries (Rwanda, Seychelles and South Africa) specially include PWDs in the coordinating structures. Therefore, most countries violate the right to participation of PWDs on issues affecting their lives; the vital principle of 'nothing about us without us' is violated. Second, although most countries identify and target key populations at higher risk of HIV exposure within their national response to HIV, less than half of the countries surveyed classify PWDs as a key population. Third, all countries have strategies to protect and promote human rights in the context of HIV within their NSPs; however, only three countries (Lesotho, South Africa and Swaziland) explicitly incorporate protection for the rights of PWDs. Fourth, only 50 per cent of countries make available HIV-related prevention services for PWDs and fewer countries provide for treatment, care and impact mitigation services. Finally, although all countries provide for monitoring and evaluation of HIV programmes, only three countries (Democratic Republic of Congo-DRC, Namibia and Swaziland) especially refer to the collection of data on disability and HIV. ${ }^{72}$

These statistics clearly show that the human rights approach or social model advocated by the CRPD does not reach HIV-positive PWDs because several African countries' responses to HIV do not include them; PWDs are not perceived as a group at risk, hence they do not receive prevention services and very few countries provide treatment or even attempt to collect data on disability and HIV. In short, HIV-positive PWDs are simply the forgotten ones. McElligott argues that " $[\mathrm{m}]$ ajor gaps in national HIV/AIDS prevention campaigns and treatment programs have made disabled people more vulnerable to HIV infection than their non-disabled counterparts'. ${ }^{73}$ The total neglect of PWDs happens in an era where the African human rights system comprises a disability law regime which will be discussed later. It is contended here that the adoption of a protocol would provide an appropriate legal framework to link HIV/AIDS and disability for the benefit of PWDs in Africa. Even if the protocol would not be a magic wand to solve all problems, it is worth trying because the CRPD does not expressly address the rights of HIV-positive PWDs. Furthermore, the right to health provided for in the African Charter ${ }^{74}$ does not explicitly cover HIV-positive PWDs. Similarly, the Committee on the Protection of the Rights of People Living with HIV and those at Risk, Vulnerable to and Affected by HIV of the African Commission has so far failed HIV-positive PWDs, as shown by the review of the NSP studies above.

Furthermore, though the thematic resolutions can make a difference in terms of promoting the rights of HIV-positive PWDs, their impact will be limited as they are more promotive than protective. Similarly, state reporting does very little to improve the rights of HIV-positive PWDs because it focuses on the rights to health without specific attention to PWDs and the Commission's general comments are

72 Gerntholtz et al, supra note 59 , p. 11.

73 McElligott, supra note 63.

74 African Charter, supra note 2 , article 16. 
generally silent on the question. The protocol should be considered in addressing this issue because the approach used so far does not work, and the guidelines that are recommended for the protocol could better address the plight of HIV-positive PWDs.

\section{The CRPD and harmful traditional practices}

To some extent, a meaningful understanding of disabilities and rehabilitation depends on specific cultural values and perceptions about disabilities. ${ }^{75}$ As mentioned earlier, discrimination against PWDs in Africa is often grounded on traditional beliefs and myths. In this light, a disability is perceived as the result of a curse or the result of an evil eye. Therefore, to cleanse PWDs of such a 'spiritual disease', they are often subjected to awful rituals and traditional exorcisms. Though the CRPD addresses this problem by calling upon the states parties to abolish or amend existing laws, regulations, customs and practices that constitute discrimination against persons with disabilities ${ }^{76}$ a clearer provision in the light of article 5 of the African Women's Protocol would have been more productive in addressing African PWDs' concerns. The article in question not only lists states' obligations in the elimination of harmful practices, but also enumerates some of these harmful practices that violate women's right in Africa. In addition, article 21 of the African Children's Charter, which reads 'Protection Against Harmful Social and Cultural Practices', is another example that, if included explicitly in a disability instrument, could assist in addressing harmful practices.

Even though the much awaited states' reports to the African Commission on Human and Peoples' Rights on the implementation of the African protocol on women's rights will testify whether the listing of shameful practices has worked for women's rights, it is suggested that an African protocol on the rights of PWDs would prohibit African practices, customs, traditions and beliefs that promote violations of disability rights. Given the diversity of the continent, such prohibitions as well as the entire protocol should be the result of a broad consultation involving members of DPOs and other continental stakeholders. It could be argued that the prohibition of harmful practice against WWDs is already addressed under article 23 of the African Women's Protocol. However, as will be shown in the section focusing on the current disability legal framework, much more must be done to shield WWDs from harmful practices.

As important as they are, the thematic resolutions can only raise awareness on the negative effects of harmful practices. So far, state reporting under the African Charter has yet to make a difference and the impact of state reporting under the African Women's Protocol is still awaited. In the same vein, no communications have been sent to the African Commission on harmful practices, hence the need to

75 E. Mpofu and D. A. Harley, 'Disability and Rehabilitation in Zimbabwe: Lessons and Implications for Rehabilitation Practice in the U.S. - Disability and Rehabilitation in Zimbabwe', 68 Joumal of Rehabilitation (2002): 26-35, at 1.

76 CRPD, supra note 5, article $4(1)(b)$. 
consider the issues through a protocol which would crystallise them in a binding norm.

\section{The CRPD and the classical African humanist philosophy of ubuntu (kinship)}

The current disability discourse is criticised for attempting to transpose the Western concept of disability as framed in the CRPD to other parts of the world. ${ }^{n}$ According to Grech, 'Western disability studies and its tenets, notably the social model of disability and the language of rights, are transferred indiscriminately from North to South and absorbed almost unquestionably by development agencies, Southern organizations and other intermediaries. ${ }^{78}$

In this vein, the shortfall of the CRPD in Africa is its failure to appreciate the African conception of a communal approach to human rights and to apply this in relation to the protection of the rights of PWDs. It has been stated that "African worldview is tempered with the general guiding principle of the survival of the entire community and a sense of cooperation, interdependence and collective responsibility'. ${ }^{79}$ Africans boast of the notion of ubuntu or batho. Ubuntu is about humanity, diversity and interdependence. ${ }^{80}$ According to Nobel Peace laureate, Desmond Tutu, ubuntu means that 'a person is a person through other persons' ${ }^{81}$ In this context, one is expected to view and treat PWDs as a reflection or extension of oneself. This approach ought to be invoked in respect to PWDs; however, the general approach taken by the CRPD contradicts Africa's conception of human rights, especially its emphasis on individualism and the independence of persons. ${ }^{82}$ For example, the CRPD provides for the right to privacy, ${ }^{83}$ which can be said to be incompatible with a communal-based conception of society. Of course, the right to privacy is important and it is not suggested that PWDs should not have the right to privacy. But this should be supplemented by the concept of ubuntu, which will benefit PWDs. The argument is that Africans also view themselves as part of a society and emphasise communalism rather than individualism only. As such, there is a need to treat disability as a community or societal issue in the African perspective and not assume that Western perspectives 'are transferrable across culture with a few modifications here and there'. ${ }^{84}$ This implies that disability should not be seen as a matter of concern to the individuals with

77 See S. Grech, 'Recolonising Debates or Perpetuated Coloniality? Decentring the Spaces of Disability, Development and Community in the Global South', 15(1) Intemational Journal of Inclusive Education (2011): 87-100; \$. Grech, 'Disability, Poverty and Development: Critical Reflections on the Majority World Debate', 24(6) Disability \& Society (2009): 771-84; S. Grech, "A Space for "Development": Engaging Social Capital in Reffecting on Disability in the Majority World", 1 Jotimal for Disability and International Development (2010): 4-13.

78 Grech, 'Recolonising Debates or Perpetuated Coloniality?', ibid., at 88.

79 J. Cobbah, 'African Values and the Human Rights Debates: An African Perspective', 9(3) Human Rights Quarterly (1987): 309-331, at 309.

80 See D. Cornell and K. van Marle, 'Exploring Ubuntu: Tentative Reflections', 5(2) African Human Rights Law Journal (2005): 195-220, at 195.

81 Tutu, sipra note 26.

82 CRPD, stapra note 5 , article $3($ a).

83 CRPD, stipra note 5, article 22.

84 Grech, 'Recolonising Debates or Perpetuated Coloniality?', supra note 77, at 88. 
disabilities and their families alone; it ought to be the concern of all communities (where PWDs live) that have the duty to supplement the role of the state.

In addition, under the umbrella of ubuntu, the crucial problem of discrimination against internally displaced PWDs (unaddressed by the CRPD) could be solved. As a result of wars and conflicts on the continent, a large number of people are internally displaced, many of whom are PWDs. The latter are often victimised and discriminated against because of their disabilities and so a solid incorporation of ubuntu in the protocol would be useful in addressing the broad discrimination faced by PWDs.

The other question that comes to mind is the need to link the disability discourse to the right to development (RTD), which is binding only in the African human rights system. ${ }^{85}$ The effects of disability on development needs should be highlighted.

These African peculiarities may not be easily achieved through the African Commission's thematic resolutions of guidelines that are soft law, nor through a self-standing treaty on disability because this would need another monitoring mechanism or body. ${ }^{86}$ The African Charter, which provides for people's duties ${ }^{87}$ towards the community, could provide an avenue, but it does not link this directly to PWDs, hence the contention that a protocol would be the appropriate means to address these specificities.

Overall, although it is absolutely true that the CRPD is likely to transform the lives of PWDs in Africa, an emphasis on disability and albinism, HIV/AIDS, the effects of harmful practices as well as a special attention to cultural specificities would have turned it into a complete document for African PWDs. In short, it is important to contextualise the CRPD to the realities of disabilities in Africa and this could be done appropriately through a protocol.

\section{The desirability of a an African protocol on the rights of PWDs in the light of the African disability legal framework}

In general, it is believed that regional human rights systems could be more effective than UN human rights arrangements because of their ability to better incorporate regional realities ${ }^{88}$ Consequently, the UN has promoted the establishment of regional systems to complement its activities in terms of human rights protection. 89

The African disability law regime means 'the past, present and ongoing's" endeavours by African states to ensure PWDs' rights under a coherent continental arrangement. Assessing the African disability law regime entails focusing on the

85 African Charter, supra note 2, article 22.

86 This will be further discussed below.

87 African Charter, supra note 2 , article 27.

88 D. Olowu, 'The Regional System of Protection of Human Rights in Africa', in Sloth-Nielsen (ed.), stipra note 15, p. 15.

89 Ibid., p. 15.

90 lbid., p. 14. 
rights of PWDs as incorporated in the African human rights system ${ }^{91}$ through treaties such as:

- the African Charter;

- the African Children's Charter;

- the African Women's Protocol;

- the African Youth Charter;

- the African Charter on Democracy;

- the Internally Displaced Persons in Africa Convention.

In addition, examining the disability law regime will also entail focusing on sub-regional undertakings for PWDs as well as on the regional non-binding instruments pertaining to the protection of PWDs.

\section{The protection of disability rights in African binding instruments}

\section{I The African Charter}

There exist numerous studies on the African Charter. ${ }^{92}$ Beside its Preamble, the African Charter contains sixty-eight articles divided into three parts with the first one dealing with 'rights and duties' (articles 1-29); the second part focusing on 'measures and safeguards' (articles 30-63) ${ }^{93}$ and the final part setting 'general provisions' (articles 64-8). The recognition of civil and political rights, socioeconomic rights and peoples' rights in the same document indicates that the African law makers intended to protect all Africans including PWDs. Article 2 reads:

Every individual shall be entitled to the enjoyment of the rights and freedoms recognised and guaranteed in the present Charter without distinction of any kind such as race, ethnic group, colour, sex, language, religion, political or any other opinion, national and social origin, fortune, birth or other status.

91 Other treaties of the African human rights system include: the 1969 African Charter Governing Specific Aspects of Refugees Problem in Africa, which entered into force in 1974; and the 1998 Protocol to the African Charter on Human Peoples' Rights Establishing the African Court on Human and Peoples' Rights, which entered into force in 2004. For more analyses of the African human rights system, see M. Evans and R. Murray (eds), The African Charter on Human and Peoples' Rights - The System in Practice, 1986-2006, Cambridge University Press (2008); V. O. Nmehielle, The African Haman Rights System: Its Laws, Practice, and Institution, Martinus Nijhoff (2001); F. Ouguergouz, African Charter on Human and Peoples' Rights-A Comprehensive Agenda for Human Dignity and Sustainable Democracy in Africa, Kluwer Law International (2003); A. Bosl and J. Diescho (eds), Human Rights in Africa-Legal Perspectives on their Protection and Promotion, Macmillan Education Namibia (2009).

92 For more on the African Charter on Human and Peoples' Rights see Evans and Murray (eds), ibid; Nmehielle, ibid:; Ouguergouz, ibid.; Bosl and Diescho (eds), ibid.; U. O. Umozurike, The African Charter on Human and Peoples' Rights, Kluwer Law International (1997); U. O. Umozurike, 'The African Charter on Human and Peoples' Rights', 77 American Joumal of International Law (1983): 902; C. Hyens, Human Rights Law in Africa, Martinus Nijhoff (2004).

93 This part is subdivided into four parts: 'Establishment and organisation of the African Commission on Human and Peoples' Rights' (articles 30-44); 'mandate of the Commission' (article 45); 'procedure of the Commission' (articles 46-59); and 'applicable principle' (articles $60-3$ ). 
The provision clearly means that 'every individual' including PWDs, is 'entitled' to the rights. In addition, besides the term 'every individual', the African Charter protects the rights of 'every human being', 'every citizen' and 'all people'. Furthermore, discrimination on the basis of certain specific grounds or 'other status [such as disability]' is prohibited. This was the position of the African Commission in the Communication Purohit and Others $v$ The Gambia ${ }^{94}$ which dealt with discrimination on the ground of disability in the Gambia. This case concerned the automatic and indefinite institutionalisation of mentally disabled persons under the Gambian Lunatics Detention Act (LDA), which practice, the complainants claimed rightfully, was discrimination on the basis of disability. In its decision, the African Commission affirmed disability as a prohibited ground of discrimination although it is not clearly mentioned under article 2 of the African Charter. $^{95}$ The Commission reiterated that all human beings regardless of their mental capabilities or disabilities are entitled to be treated with dignity, which is an inherent basic right. ${ }^{96}$ As such, reference to mentally disabled persons as 'lunatics' and 'idiots' under the LDA was found to be both dehumanising and an insult to their dignity. ${ }^{97}$ The African Commission also affirmed that mentally disabled persons are entitled to participate in electoral processes in their countries. It also declared that the right to political participation under the African Charter is extended to 'every citizen' and its denial can only be justified by reason of legal incapacity, which may not necessarily mean mental incapacity. Finally, the African Commission observed that states should take tangible and targeted steps to ensure the right to health of everyone including PWDs.

This interpretation of article 2 of the African Charter is similar to the one provided by the Committee on Economic Social and Cultural Rights (Committee on ESCR) in its General Comment Number 5 on the rights of PWDs. In this regard, after the omission of the rights of PWDs in the International Covenant on Economic Social and Cultural Rights (IESCR), the Committee on ESCR explained the obligation contained in article 2(2) of the Covenant to mean that the rights 'enunciated... will be exercised without discrimination of any kind' based on certain specified grounds 'or other status' obviously relates to discrimination on the grounds of disability.

Nevertheless, this approach that incorporates the rights of PWDs under a universal provision through which these rights should be deduced has a limited

94 Purohit and Others $v$ The Gambia, (2003) AHRLR 96 (ACHPR 2003).

95 Purohit case, ibid., para. 61: "The Commission maintains that mentally disabled persons would like to share the same hopes, dreams and goals and have the same rights to pursue those hopes, dreams and goals just like any other human being. Like any other human being, mentally disabled persons or persons suffering from mental illnesses have a right to enjoy a decent life, as normal and full as possible, a right which lies at the heart of the right to human dignity. This right should be zealously guarded and forcefully protected by all states party to the African Charter in accordance with the well established principle that all human beings are born free and equal in dignity and rights.'

96 Purohit case, supra note 94 , para. 57.

$97 \mathrm{Hbid}$, para. 59.

98 Committee on Economic, Social and Cultural Rights, General Comment No. 5, Persons with Disabilities (Eleventh session, 1994), UN Doc E/1995/22 at 19 (1995), para. 5. 
impact on the rights of the beneficiaries. Stein and Lord correctly observe that " $[\mathrm{t}]$ he principal difficulty with this approach is that existing human rights obligations are not tailored to address the specific barriers faced by persons with disabilities in the realisation of their human rights. ${ }^{.99}$ Similarly, Kayess and French argue that incorporating the rights of PWDs in a universal provision will not enhance 'the recognition and respect' ${ }^{100}$ of rights of the beneficiaries because,

[t]o a significant extent, the traditional human rights paradigm is based on an 'able-bodied' norm. [And that] [i]n most cases it is not selfevident how traditional human rights are to be interpreted and applied. in a manner that will penetrate to the specific human rights violations to which persons with disability are subject. ${ }^{101}$

However, this shortcoming was purportedly corrected by article 18(4), which provides that "[t]he aged and the disabled shall also have the right to special measures of protection in keeping with their physical and moral needs'. Nevertheless, this provision still fails PWDs for three reasons. First, it is incorporated into a general disposition without conferring substantive rights to PWDs. Second, the 'specific measures of protection' to be afforded to PWDs are vague and unclear, though they could be understood to mean affirmative actions. Third, the provision mixes the rights of PWDs with those of the aged, thus mixing the rights and contexts of two different categories. Viljoen and Biegon argue that '[b]y mentioning disability in the context of old age, specifically, the African Charter curtailed the evolution of a full, nuanced and multi-faceted understanding of disability.' ${ }^{102}$ This reduces the possibility to efficiently address disability right through the African Charter.

The lack of adequate focus on the rights of PWDs has also reached the African Commission which until $2009,{ }^{103}$ had not prioritised disability rights. Biegon correctly observes that though 'the African commission has adopted numerous thematic resolutions elaborating the provisions of the African Charter, [none of them] has focused on disability rights'. ${ }^{104}$ Therefore, the African Commission fails to promote the rights of PWDs. ${ }^{105}$ Similarly, the African Commission does not use its Concluding Observations to criticise states that fail to report on disability rights (article $18(4)$ of the Charter). For instance, in considering the Cameroon Periodic Report at its 39 th Ordinary Session, the

99 Stein and Lord, supra note 36, p. 19.

100 Kayess and French, supra note 39.

101 lbid.

102 Viljoen and Biegon, supra note 27, p. 14.

103 During the Commission's 45th ordinary session, the Focal Point on the Rights of Older Persons was transformed into Working Group on the Rights of Older Persons and People with Disabilities in Africa. See Resolution on the Transformation of the Focal Point on the Rights of Older Persons in Africa into a Working Group on the Rights of Older Persons and People with Disabilities in Africa, ACHPR/Res 143 (XXXXV) 09.

104 Biegon, supra note 23.

105 Article 45(1) of the ACHPR provides for the promotive mandate of the African Commission. African Charter, supra note 2. 
African Commission raised its concerns on the rights of vulnerable groups as follows: 'The situation of vulnerable groups in general and in particular that of street children and of indigenous populations/communities and human rights defenders remains precarious. ${ }^{106}$ Nothing is said about the rights of PWDs who are often discriminated against in the country. In fact, the inappropriate coverage of disability rights in the African human rights system has impacted negatively on the development of an African jurisprudence on the question. Hence, to date the African Commission has received only one communication dealing with the rights of PWDs: Purohit and Others $v$ The Gambia ${ }^{107}$ discussed earlier. Though this case has the potential to advance disability rights, PWDs remain invisible, even during the African Commission's sessions where the proceedings are not translated into sign language. ${ }^{108}$ In addition, as mentioned earlier, the other entry point to protect the rights of PWDs is the right to the 'best attainable state of physical and mental health' under the African Charter. ${ }^{109}$ Nevertheless, this provision is more inclined to protect able-bodied people's health. Furthermore, it reduces disability to a mental problem, which is an emphasis on the medical model of disability that is no longer recommended.

The point here is that the mainstreaming of disability rights in the African Charter provides a limited avenue for the protection of the beneficiaries. The thematic resolutions and the Concluding Observations of the African Commission do not necessarily benefit PWDs, hence the contention that a protocol would offer a better protection of African PWDs. A protocol would increase the visibility of PWDs and enhance the prospects of having more communication about their rights, even though the inertia of PWDs DPOs should also be blamed for the lack of communication at the Commission. ${ }^{10}$ The fact that the adoption of the African Women's Protocol did not produce more communication on women's rights violations should not be a deterrent to strengthen the African disability law regime with a protocol, because the latter would at least improve standards setting in Africa.

\subsection{The African Children's Charter}

The African Children's Charter is known to be the most progressive regional response to children's rights as, among others, it captures African children's 'cultural heritage, historical background, and the value of African civilization'. ${ }^{111}$ It places the child at the centre of society, in which his full development should be ensured within a family environment characterised by happiness, love and compassion. ${ }^{112}$ However, like article 2 of the African Charter discussed above,

106 African Commission on Human and Peoples' Rights, 39th Ordinary Session, 11-25 May 2005, Banjul, The Gambia, 'Consideration of Reports Submitted by States Parties under Article 62 of the African Charter on Human and Peoples' Rights', para. 13.

107 Purohit case, supra note 94.

108 Viljoen and Biegon, supra note 27, p. 22

109 African Charter, supra note 2, article 16.

110 lbid.

111 A. Lloyd, 'The African Regional System for the Protection of Children's Rights', in SlothNielsen (ed.), supra note 15, p. 33.

112 lbid., p. 33. 
children with disability are covered only incidentally through the general nondiscrimination provision. ${ }^{113}$ This approach fails to ensure the visibility of the rights of children with disabilities. ${ }^{114}$ Therefore, in the same way that the African Children's Charter 'emerged out of the sentiment that the Convention on the Rights of the Child ignored ... realities" of the African child, ${ }^{115}$ there is a need to adequately protect African children with disability. One of the methods recommended in an African protocol on the rights of PWDs, would be to use the approach prescribed by the $\mathrm{CRC}^{116}$ in which the rights of children with disabilities are clearly expressed.

It is important, however, to applaud article 13 of the African Children's Charter, which provides for the rights of children with disabilities, though it reduces disability to mental or physical impairments only. ${ }^{117}$ Still on a positive note, article 13(2) should also be applauded for emphasising states' obligation in accommodating children with disabilities, and for not linking assistance to these children to their parents' circumstances, but to the child-specific situations. ${ }^{118}$ Nevertheless, unlike the $\mathrm{CRC},{ }^{119}$ the African Children's Charter failed to include education, health care and rehabilitation facilities among the services that children with disability are entitled to. It is important to ensure access to all public and private spheres as this has been a serious problem for children with disabilities.

As far as state reporting is concerned, it is problematic because countries do not always comply with the guidelines of state reporting under the African Children's Charter. Therefore, reporting on children with disabilities is far from being 'uniform and systematic'. ${ }^{120}$ This is aggravated by the inconsistency of the Children Committee's Concluding Observations or Recommendations on implementing the rights of children with disability. These factors limit the reliability on state reporting and Concluding Observations to address the rights of children with disabilities, hence the suggestion to attempt to solve the problem through a protocol that, in spite of its weaknesses, will at least enhance the visibility of the beneficiaries of the rights.

\subsection{The protocol on the right of women in Africa}

Similar to the African Children's Charter, the emergence of the African Women's Protocol ${ }^{121}$ was due to the failure of the Convention on the Elimination of All

113 African Children's Charter, supra note 2, article 3.

114 M. Gose, The African Charter on the Rights of the Child (2002), pp. 47-8, quoted in Combrinck, supra note $15, \mathrm{p} .310$.

115 Olowu, stipra note 88, p. 23; also F. Viljoen, 'State Reporting Under the African Charter on Human and Peoples' Rights: A Boost from the South', 44(1) Joumal of African Law (2000): $110-18$

116 General Assembly adopted the Convention and opened it for signature on 20 November 1989 and it came into force on 2 September 1990: see Convention on the Rights of the Child, article 2.

117 African Children's Charter, supra note 2, article 13(1).

118 Combrinck, supra note 15, p. 311.

119 Convention on the Rights of the Child, supra note 116 , article $23(3)$.

120 Viljoen, supra note 22 , pp. $26-7$.

121 For more insight on the African Women's Protocol, see F. Viljoen 'An Introduction to the Protocol to the African Charter on Human and Peoples' Rights on the Rights of Women in Africa', 16 Washington and Lee Journal of Civil Rights and Social Justice (2009): 11-45. 
Forms of Discrimination against Women (CEDAW) ${ }^{122}$ and even the African Charter to cover African women's rights adequately. ${ }^{123}$ In supplementing the CEDAW, the African Women's Protocol addresses issues peculiar to African women. ${ }^{124}$ In this regard, it deals with domestic violence, ${ }^{125}$ polygamy ${ }^{126}$ and HIV/AIDS. ${ }^{127}$ In addition, it provides for women's rights in situation of armed conflicts; ${ }^{128}$ and prohibits violence against women including harmful practices such as female genital mutilation. ${ }^{129}$ The incorporation of "specific African sociocultural peculiarities' in the African Women's Protocol led Viljoen to argue that the African document 'locates the CEDAW in African reality'. ${ }^{130}$

In supplementing the African Charter, the African Women's Protocol goes beyond 'the broad provisions regarding the right to equality and freedom from discrimination' 131 contained in articles 2 and 18(3) of the African Charter. Furthermore, in addressing women's rights specifically, it corrects article $18(3)$, which lumps women and children together; more importantly, it provides for 'Special Protection of Women with Disabilities' in its article 23. In terms of article 23(a) of the protocol, states parties have undertaken to 'ensure the protection of women with disabilities' and particularly to 'take specific measures commensurate with their physical, economic and social needs to facilitate their access to employment, professional and vocational training as well as their participation in decision-making'. Article 23(b) also compels states to 'ensure the right of women with disabilities to freedom from violence, including sexual abuse, discrimination based on disability and the right to be treated with dignity'. At first sight, this provision is enough for the protection of WWDs in Africa. It addresses the plight of these women by ensuring their visibility and ensures a 'de facto equality', ${ }^{132}$ thus the African Women's Protocol should be commended for containing this provision. However, the rights of WWDs are broad, multifaceted and complex and therefore cannot be adequately covered in a single provision. Though article 23 lists important concerns of WWDs such as 'freedom from violence, including sexual abuse, access to employment,

122 Olowu, sipra note 88, p. 23.

123 K. A. Ebeku, 'A New Hope for African Women: Overview of Africa's Protocol on Women's Rights', 13(3) Nordic Journal of African Studies (2004): 264-74, at 273; also Djoyou Kamga, stipra note 18, pp. $1,6$.

124 For more on these issues, see F. Viljoen, Internationat Human Rights Law in Africa, Oxford University Press (2007), pp. 266-76.

125 African Women's Protocol, supra note 2, article 4(2).

126 lbid, article 6(c).

127 lbid, article $14(1)(\mathrm{d})(\mathrm{e})$.

128 lbid., article 11.

$129 \mathrm{rbid}$, anticle 5.

130 Viljoen, stipra note 124, p. 271.

131 S. B. Keetharuth, 'Major African Legal Instruments', in A. Bosl and J. Diescho (eds), Human Rights in Africa-Legal Perspectives on Their Protection and Promotion, Macmillan Education Namibia (2009), p. 180.

132 S. Arnade and S. Haefner, 'Gendering the Draft Comprehensive and Integral International Convention on the Protection and Promotion of the Rights and Dignity of Persons with Disabilities", legal background paper (2006), p. 21, available at http:/www.wwda. org.au/dpi 1.pdf (accessed 10 November 2010). 
professional and vocational training, participation in decision-making', it is silent on access to education and health care that are vital for WWDs' empowerment. Arnade and Haefner correctly observe:

[AII] specific reference to the problems faced by women with disabilities is necessary to make women with disabilities and the issues that affect them differently or disproportionately visible and to increase the likelihood that they will be addressed by governments and others in the implementation [process]. ${ }^{133}$

The shortage of full references to WWDs' concerns is due to the fact that they could not be lumped in a single provision. The African Women's Protocol follows in the footsteps of the African Charter. In this respect, it lumps the rights of WWDs together in a single provision, as women's rights are in the African Charter. Therefore, just like the African Charter was a precursor for a better protection of women' rights through the African Women's Protocol, the latter should be considered as a catalyst for a better protection of the rights of WWDs through the adoption of a protocol on the rights PWDs.

Furthermore, article 23 speaks of 'specific measures commensurate with the needs' of women with disabilities. This is vague and cannot ease the monitoring of state compliance with the rights of WWDs. This shortcoming could be addressed by the incorporation in the African Protocol of explicit prescriptive measures to protect and ensure access for and to accommodate WWDs in all parts of life. As it stands, article 23 of the African Women's Protocol does not deal with the fact that WWDs are excluded both for being women and for being PWDs.

However, the state reporting under the African Women's Protocol is an avenue to cover WWDs. The guidelines for state reporting clearly call on states to explain the legislative, administrative, institutional and policy measures that they have taken to give effect to the provisions of the protocol. Nevertheless, the size and specificities of discrimination against WWDs are complex. For instance, ensuring access to education for women and girls with disabilities will not be accomplished through a few pieces of legislation and policies on universal access to education. Access to education in this context is broader as there is a need to have inclusive access as well as accommodation measures commensurate with various types of disabilities. The same observation applies to other areas of concern for WWDs, such as access to health, to work and employment, and to protection against violence and abuse. Though the guidelines are welcomed, they may not do justice to all WWDs.

In spite of the adoption of guidelines, as mentioned earlier, states' reports as well as concluding observations are still awaited. Similarly, communications on the violation of rights of women and WWDs are still awaited and this casts doubts on the ability of a disability rights protocol to really change the fortune of PWDs. Nevertheless, a protocol on disability would at least reinvigorate the discussion on the question and reinforce the African human rights system. Overall, though 
the African Women's Protocol should be applauded for inserting a provision on the rights of WWDs, this should be considered as the first step to be broadened through the adoption of a continental protocol on the rights of PWDs. Without being a magical solution, this would definitely strengthen the continental human rights architecture.

\subsection{The African Youth Charter}

The African Youth Charter ${ }^{134}$ is the legal framework guaranteeing the rights of young people on the continent. The Youth Charter comprises a Preamble and two parts. The first part, divided into twenty-eight articles, provides for the 'rights and duties of youth', while the second part, comprising three articles, focuses on the '[f]inal provisions' related to the savings clause, signature, ratification or adherence as well as amendment and revision.

Under the African Youth Charter, states parties undertake to protect the rights of young people to own property, enjoy freedom of movement, of expression, of association and religion. The Charter also caters for the RTD, privacy, participation, education, culture, health care, poverty reduction and employment among others. Panday observes:

[T]he adoption of the Charter is a victory for youth across the continent as it creates a legally binding framework for governments to create supportive policies and programmes for youth. It also provides a platform for youth to assert their rights and execute their responsibility to contribute to the development of the continent. ${ }^{135}$

The African Youth Charter, like other continental treaties covers youth with disabilities only under the general non-discrimination provision. ${ }^{136}$ As highlighted earlier, through this approach, 'the particular vulnerability and disempowerment arising from [the disability] will be submerged into the general concern about the state of human rights'. ${ }^{137}$

The second coverage of youth with disabilities is provided by article 24 , which protects 'mentally and physically challenged youth'. The latter are afforded the right to special care and to equal and effective access to education, training, healtheare services, employment, sport, physical education, and cultural and recreational activities. ${ }^{138}$ In addition, states parties are compelled to work towards eliminating any obstacles that may have negative implications for the full integration of youth with mental and physical disability. However, not only does

134 For more on the African Youth Charter, see D. Mac-Ikemenjima, 'Beyond Banjul: It's Time to Implement the African Youth Charter' (2009), available at http//afrimap.org/english/mages/ paper/AfriMAP-AYC-Macikemenjima-EN.pdf (accessed 26 April 2011); also L. Isa-Odidi, 'The African Youth Charter: An Opportunity for African Leadership in Development' (2009), available at http://afrimap.org/ (accessed 26 April 2011 ).

135 S. Panday, 'African Youth Charter? A Benchmark for Youth Development in Africa', Human Science Research Council, Media Brief (2006), available at http:/www.hsrc.ac.za/Media Release-276.phtml (accessed 26 April 2011 ).

136 Aftican Youth Charter, stipra note 2, article 2.

137 Viljoen, supra note 31, p. 82.

138 African Youth Charter, supra note 2, article 24(1). 
this provision reduce disability to mental and physical impairment, it focuses on the impairments perceived as challenges and not on societal hindrances to disability rights. This approach is still centred on the medical model and does not enhance the right of PWDs. The provision also emphasises the impairment of the individual and "may thus be understood as being derogatory and could consequently reinforce stigmatization'. ${ }^{139}$ Therefore, such approach should be turned towards a human rights approach model through the adoption of a protocol on the rights of PWDs.

Unlike with other treaties, the monitoring of the African Youth Charter is the responsibility of the African Union Commission (AUC), which is not a judicial or quasi-judicial body. In discharging its duties, the AUC is supposed to collaborate with governments, non-governmental institutions and development partners to identify and share good practices. Therefore, there is no traditional state reporting, thematic guidelines and communications. This approach disharmonises the disability law regime, and it is suggested that the continent needs a uniform regime that could well be structured in a protocol.

Besides the four treaties discussed above, the African Charter on Democracy and the Convention on Internally Displaced Persons in Africa also provide for the rights of PWDs; $;^{140}$ however, these two instruments are yet to enter into force, hence their limited impact. ${ }^{141}$ In addition to the instruments discussed, subregional treaties originally adopted to ensure economic integration also cater for the rights of PWDs. In this regard, the East African Community Treaty, ${ }^{142}$ the Treaty of the Southern African Development Community (SADC), ${ }^{143}$ the SADC Protocol on Gender and Development, ${ }^{144}$ the SADC Charter of Fundamental and Social Rights ${ }^{1+5}$ and the Treaty of the Economic Community of West African States ${ }^{146}$ all provide for the rights of PWDs. Though these instruments clearly provide for the rights of PWDs, they remain fragmented and could be harmonised and made visible in a protocol which could include a broad variety of African disability concerns.

Overall, the mainstreaming of PWDs in African binding instruments and other international instruments has good prospects for enhancing the rights of

139 Viljoen and Biegon, supra note 27, p. 16.

140 Charter on Democracy, supra note 3, articles 8, 31 and 43; IDP Convention, supra note 3, article $9(2)(\mathrm{c})$.

141 For more on this, see Viljoen, supra note 22.

142 Article $120(\mathrm{c})$ of the East African Community Treaty, signed 30 November 1999 and entered into force 7 July 2000. See http://www.eac.int/treaty/index.php (accessed 3 March 2013).

143 Article 6(2) of the Treaty of the Southern African Development Community (SADC), adopted in 1992 and entered into force in 1993. See SADC http:/www.sadc.int (accessed 3 March 2013).

144 Article 9 of the SADC Protocol on Gender and Development, adopted 17 August 2008 but not yet entered into force. See http:/www.sadc.int/documents-publications/show/803 (accessed 3 March 2013).

145 Article 9 of the SADC Charter of Fundamental and Social Rights, adopted 1 July 2003 . See http:/www.sadc.int/documents-publications/show/803 (accessed 3 March 2013).

146 Article 4(g) of the Treaty of the Economic Community of West African States, adopted 28 May 1975. See http:/www.ecowas.int (accessed 3 March 2013). 
beneficiaries. It should not stop endeavours to better the guarantee of these rights, and this could be done through a protocol. Mutua correctly observes:

The existence of a general scope human rights documents, in which everyone is protected, such as the ICCPR, does not obviate the need for a specific instrument targeted at a particular class of people or problem. That is why the female gender, which is guaranteed by all the rights in the ICCPR, still needs its own specific normative framework to address the particular problems and conditions that attach to it by virtue of its difference. The same is true with racial groups, minorities, indigenous peoples, workers, children, and other classes, categories or groups with shared historical, ethnic, religious, social, linguistic, cultural or other characteristics. It is only by recognizing these differences and specifically addressing them that society can ensure the victims equal protection. This is the reason why disabled people have sought a normative framework to address their plight. ${ }^{147}$

\section{Disability rights in African non-binding instruments}

Following the pattern set at global level with the adoption of several non-binding disability laws instruments, ${ }^{148}$ the African continent has undertaken numerous initiatives. The 1999 OAU first Ministerial Conference on Human Rights, ${ }^{149}$ which produced the Grand Bay (Mauritius) Declaration and Plan of Action, ${ }^{150}$ mixes together the right of PWDs, people living with HIV/AIDS, women and children. ${ }^{151}$ This initiative was followed by the proclamation of the period of 1999-2009 as the African Decade of Disabled Persons by the OAU Council of Ministers and the Assembly of State and Government in July 2000 in Lome, Togo.

In 2000 , the advent of the $\mathrm{AU}$ brought more emphasis on human rights on the continent. ${ }^{152}$ In addressing disability rights, at its very first ordinary session, the AU Executive Council adopted the Continental Plan of Action for the African Decade of People with Disabilities. This instrument was intended to enhance the capacity of governments and other stakeholders to ensure the rights of PWDs in Africa. Subsequently, at the 2003 AU Ministerial Conference held

147 M. Mutua, "Standard Setting in Human Rights: Critique and Prognosis", 29 Human Rights Quarterly (2007): 547-623, at 623 .

148 The declaration of the year 1981 as UN International Year of Disabled Persons, the declaration of the decade 1983-93 as UN Decade of Disabled Persons, the adoption of the 1983 World Programme of Action Concerning Disabled Persons, the adoption of the 1993 UN Standard Rules on the Equalization of Opportunities for Persons with Disabilities.

149 The Conference was held in Grand Bay, Mauritius.

150 Grand Bay (Mauritius) Declaration and Plan of Action, reprinted in Hyens and Killander, supra note 2 , pp. 155-9.

151 lbid., para. 7.

152 According to the AU Constitutive Act, article 3(h), one of the objectives of the AU is to 'promote and protect human and peoples' rights in accordance with the African Charter on Human and Peoples' Rights and other relevant human rights instruments'. AU Constitutive Act adopted in Lome, Togo, 11 July 2000 and entered into force 26 May 2001. See http:/wwwafricaunion.org/rootau/aboutau/constitutive_act_en.htm (accessed 3 March 2013). 
in Kigali, Rwanda highlighted the importance of the concerns of the elderly and PWDs. ${ }^{153}$ This initiative was followed by the Disability African Regional Consultative Conference (held in Johannesburg, South Africa), which provided for the establishment of the SADPD in 2004 with its headquarters in Pretoria, South Africa. The SADPD is in charge of five key programmes in the following areas: HIV/AIDS, youth and children, gender, law and policy, and livelihood opportunities and poverty reduction. These programmes are operational in some African countries ${ }^{154}$ while national African Decade Steering Committees have been established in sixteen other countries. ${ }^{155}$

Another regional initiative of significance is the Africa Campaign on Disability and HIV/AIDS, launched in 2007, which brings together PWDs and AIDS organisations to work for the integration of disability rights within HIV policies and programmes in Africa. The Second Meeting of the Africa Campaign led to the development and signing of the 2008 Kampala Declaration on HIV, which calls on states and other regional stakeholders to link disability in all aspects of the response to HIV as provided for in the 2008 Kampala Declaration on Disability and HIV and AIDS. ${ }^{156}$ Pursuant to these initiatives, in 2009, the AU declared $2010-19$ as the second African Decade on the Rights of Disabled Persons. ${ }^{157}$

As much as the continent could be applauded for attempting to address disability rights through these initiatives, the latter are non-binding on states, hence their impact has been limited. All these vague and soft initiatives are not irrelevant, but could be perceived as moments of 'struggles in the darkness" in an attempt to reach the light which will appear through the adoption of a hard, binding instrument in the form of a protocol. Non-binding norms cannot supersede a binding one. It would be difficult to consider non-binding $\mathrm{AU}$ decisions, declarations, codes of conduct and guidelines as appropriate legal avenues for the protection of the rights of PWDs. This could amount to a 'risky form of legal gymnastics ${ }^{159}$ which will not advance the rights of PWDs on the continent.

Notwithstanding the risk of producing a document characterised by duplications of existing laws, the wastage of time and resources and the risk of non-implementation at domestic level, the protocol would consolidate and create harmony between the various continental undertakings on disability law. It would

153 The 1st AU Ministerial Conference on Human Rights in Africa, 8 May 2003, in Kigali, Rwanda, para. 20; MIN/CONF/HRA/Decl.1 (1). See http:/www.africa-union.org/Structure_of_the Commission/Political\%20Affairs/X/KIGALI\%20DECLARATION\%20as\%20adopted $\% 20 \mathrm{in} \%$ 20Kigali.pdf (accessed 3 March 2013).

154 Ethiopia, Kenya, Rwanda and Senegal.

155 Burkina Faso, Burundi, Cameroon, Cape Verde, Egypt, Gambia, Ghana, Guinea, Mali, Mauritania, Namibia, Senegal, South Africa, Tanzania, Togo and Zambia.

156 For more on this, see Gerntholtz et al, supra note 59, p. 16.

157 AU Executive Council Resolution EX.CL/477 (XIV), adopted during the 14th ordinary session of the African Heads of State and Government, 26-30 January 2009, Addis Ababa, Ethiopia.

158 Kayess and French, supra note 39, p. 12.

159 G. Alfredsson, 'The Right to Development: Perspective from Human Rights Law', in L. A. Rehof and C. Gulmann (eds), Human Rights in Domestic Law and Development Assistance Policies of the Nordic Countries, Kluwer Academic Publishers (1989), p. 84. 
assist to merge them in a comprehensive and single approach to disability, ${ }^{160}$ which may lead to a better implementation. Based on the analysis above, the next section will consider a potential content of the recommended protocol.

\section{POTENTIAL CONTENTS OF THE PROTOCOL ON THE RIGHTS OF PWDS IN AFRICA}

At the outset, it is important to note that this is a brief overview of the nonexhaustive content of the potential protocol which should be the product of a broad consultation with DPOs driving the process. Given that the protocol should supplement the global instrument and the continental disability law regime, the specific African document should contain African peculiarities. Among others, it should reflect the African communitarian way of life from a disability perspective; the kinds of disability experienced on the continent, for example, leprosy and albinism. Furthermore, the continental protocol should prohibit African practices, customs, traditions and beliefs that promote violations of disability rights; and it should factor the impact of disability on development needs, as this will reflect the continental adhesion to the RTD that is binding in the African Charter.

Specific rights should be well articulated. In this respect, it is important to provide for full protection of civil, political and socio-economic rights of PWDs commensurate with their specific needs. ${ }^{161}$ This should entail a 'reasonable accommodation' of the beneficiaries. In this vein, the rights of the most vulnerable, such as WWDs and children of internally displaced people with disabilities, should be clearly stated. Special emphasis should be given to the right of WWDs who suffer double discrimination. These women need additional and explicit protection in terms of access to health, education, work and employment, as well as protection against sexual violence and other abuses. ${ }^{162}$

As far as the right to health is concerned, states parties should recognise that WWDs are entitled to the highest attainable standard of physical and mental health without discrimination on the ground of disability. They should undertake to ensure that all appropriate measures are taken to grant access for WWDs to health services, including health-related rehabilitation. Specifically, states parties shall: (a) provide WWDs with the same range and standard of services as provided for other women (including sexual and reproductive health services); (b) ensure that WWDs are empowered to decide freely and responsibly on the number and spacing of their children, without discrimination based on disability. To that end, states parties shall develop and disseminate policies and programmes in fields such as family planning and parenthood, pregnancy, childbirth and the post-natal period that are inclusive to WWDs and protect them against any form of coercive treatment.

160 K. Kithure, 'The African Human Rights System: Unnecessary Overlaps or Useful Synergies?', 12(2) East African Joumal of Peace and Haman Rights (2006): 318-32, at 319.

161 For more on this, see Mureriwa, supra note 24.

162 This subsection is informed by Djoyou Kamga, supra note 18, pp. 7-9. 
As for the right to education, from a reasonable accommodation perspective, states parties must ensure that WWDs benefit from educational curricula and skills development that do not perpetuate gender and disability stereotypes and stigmatisation; and ensure an environment in which girls and WWDs can learn without harassment, and have access to gender and disability-sensitive services.

In addressing the right to work and employment, states parties should consider the needs of WWDs during pregnancy, childbirth and child care. This will help eradicate the perception that these women are asexual and cannot start their own family.

As far as freedom from exploitation, sexual violence and other abuses are concerned, states parties should be compelled to take all appropriate legislative, administrative, social, educational and other measures to protect WWDs, both within and outside the home, from all forms of exploitation, sexual violence and other abuses.

It is important, however, to note that these provisions will be meaningless if states parties are not obliged to adopt legislative, administrative and institutional measures to guarantee the rights of PWDs. Therefore, on institutional measures, the protocol should set up a working committee on disability rights in the African Commission composed of experts including PWDs, with a mandate to research, promote and use their expertise for the expansion of disability rights. In addition, monitoring disability rights should be the responsibility of the African Commission through state reporting and communications, and their justiciability should be ensured by the Commission and the African Court of Justice and Human Rights.

In addition to these measures, the protocol could offer the possibility to include reservations by states parties, provided such reservations remain compatible with the object and purpose of the protocol that aim to guarantee disability rights.

\section{CONCLUDING REMARKS}

This paper calls for the adoption of a protocol to the African Charter on the rights of PWDs. In doing so, the paper assesses the other exiting mechanisms to address disability rights. It shows that the lack of consultation that characterised the Accra draft, and its lack of conceptual clarifications and appropriate substance among other shortcomings should not stop Africa from considering the adoption of a protocol. In addition, the paper assesses the mechanisms in place such as the current CRPD, the mainstreaming of disability rights in the African human rights system and the activities of the African Commission. Due to the fact that the CRPD does not adequately address African realities (such as albinism, HIV/AIDS, continental harmful practices and the communitarian way of life), the paper argues for the adoption of a protocol which must take into account the African contexts.

The paper also calls for a protocol on the ground that though the mainstreaming of disability rights in the regional system is commendable, PWDs' rights are 
fragmented and dispersed and do not directly refer to the beneficiaries who remain invisible. It is expected that the protocol would harmonise all documents and provisions related to disability rights.

The paper is also of the view that the African Charter state reporting mechanism does not do justice to PWDs and this is aggravated by the silence of the African Commission's Concluding Observations on disability rights. Similarly, in spite of their great potential, the African Commission's thematic resolutions of guidelines do not focus on disability rights and so far only one communication on disability has been brought to the Commission. Furthermore, the Working Group should be separated in two with one working full-time on disability rights while the other focuses on the elderly.

Though the protocol has its own weaknesses such as time and resources consumption, the risk of duplication of existing laws, and the risk of it being completely watered down at domestic level, its adoption does not entail a new monitoring institution as the African Commission is already functioning. A protocol should supplement the CRPD, the continental disability law architecture, thereby strengthening the regional human rights system as a whole. As much as the protocol should guarantee civil and political and socio-economic rights of PWDs, it should emphasise the specific protection of WDDs that are usually forgotten. Furthermore, the protocol should contain the African communitarian way of life from a disability perspective as this will assist in eradicating discrimination on the ground of disability. Moreover, it should address disability within the context of HIV/AIDS; prohibit African practices, customs, traditions and beliefs that promote violations of disability rights; and factor the impact of disability on development needs. It is argued in this paper that though the protocol is not the only solution for disability problems in Africa, it can enhance the prospects for a better protection of PWDs in Africa. It also has the advantages of harmonising disability rights on the continent and complementing the African human rights architecture that remains incomplete without a specific binding instrument on the rights of PWDs. 